\title{
Semiotisk vidensorganisering i teori og praksis
}

\author{
Af Torkild Thellefsen
}

\section{Introduktion}

Semiotikken har for længst holdt sit indtog i biblioteksvidenskaben. Søren Brier beskrev op igennem 90'erne et informationsbegreb netop forankret i den pragmatiske semiotik bl.a. tilsat biologi og systemteori, og konkluderede at LIS med dets statistiske metoder til dataindsamling ikke kunne håndtere videns- og informationsbegrebets kompleksitet. Birger Hjørland har ikke arbejdet direkte med semiotikken, men har alligevel et tegnbegreb i sin vorden primært baseret på psykologen Benny Karpatschof. JensErik Mai har publiceret dele af sin ph.d. afhandling, som omhandler indekseringsteori og semiotik, hvor specielt emne problematikken er i fokus i forbindelse med indeksering af dokumenter. Fællesnævneren for disse tre nævnte forskere er, at de vender sig bort fra en rationalistisk, mekanisk og objektiv forståelse af vidensbegrebet. De kunne formentlig enes om et vidensbegreb funderet $\mathrm{i}$ en objektiv eksisterende verden, hvor viden konstrueres i forskellige systemer uafhængigt af det enkelte individ. Naturligvis er det det enkelte individ, der tolker de tegn det står overfor, men det er tegnets videnspotentiale, der i en stor udstrækning determinerer fortolkningens indhold. Dette aspekt vender jeg tilbage til.

Nuvel, hvad der yderligere er fælles for de tre ovennævnte forskere er imidlertid, at ingen af dem har udviklet alternativer til de universelle klassifikationssystemer. De har heller ikke udviklet metoder til at organisere viden indenfor vidensdomæner, som bryder med de universalistiske idéer. Denne mangel på praksisgørelse af semiotikken gør, at den har endog meget svært ved at vinde indpas $\mathrm{i}$ LIS både nationalt og internationalt, og det er ikke så mærkeligt. Hvad skal man med komplekse og svære teorier, hvis de ikke kan anvendes i praksis? Naturligvis skal et forskningsfelt udvikle sit epistemologiske udgangspunkt og grundlag, men det er nødvendigt at forholde sine teorier til den faktiske verden, i dette tilfælde den verden bibliotekarer og andre informationsspecialister færdes i. Men som Brier $(1994,1996)$ i sin forskning har påvist, så kan semiotikken bruges til radikalt at ændre vores opfattelse af vidensbegrebet, og det er på dette epistemologiske plan at Briers kybersemiotik får betydning for LIS; et epistemologisk plan som jeg erklærer mig 
enig $i^{1}$ og som jeg mener, er muligt at videreudvikle både teoretisk og praktisk. For det er nødvendigt at praksisgøre dette epistemologiske fundament. Men det betyder, at vi må stikke dybere i semiotikken end det normalt er kutyme i LIS forskningen. Vi må bort fra den antropocentriske fordom, at tegn kun hidrører menneskets erkendelse, det er nødvendigt at erkende at tegn eksisterer udenfor den menneskelige bevidsthed (også menneskeskabte tegn), og at tegnene tvinger os til at tolke dem på en bestemt måde, ellers kan vi simpelthen ikke forstå tegnenes videnorganisatoriske og autopoietiske adfærd. Jeg har i andre artikler plæderet for, at man kan opfatte fagbegreber som kognitive satellitter, fordi fagbegreber afspejler den måde vi kognitivt organisere viden på, og fordi fagbegreber så at sige bliver sendt i kredsløb over vidensdomænets aktører og opfører sig som autopoietiske størrelser. Konsekvensen af denne måde at anskue tegn på er, at vi får et realistisk forhold til tegnene, dvs. at den pragmatiske semiotik per se er antinominalistisk, antirationalistisk, pragmatisk, dynamisk og evolutiv. Og det er med udgangspunkt heri at jeg vil præsentere de teorier, jeg har udviklet gennem mit ph.d. studie og efterfølgende vise eksempler på hvilken betydning teoridannelsen har for et vidensdomæne som ergoterapi. Nedenfor følger en kort gennemgang af baggrunden for den semiotiske vidensorganiseringsmetode: SKO (Semiotic Knowledge Organization). Dernæst følger en beskrivelse af det vidensdomæne metoden udfoldes på, med henblik på at definere begrebet fundamentaltegn. Efterfølgende beskriver jeg det fortløbende projekt mellem Aalborg Universitet, Danmarks Biblioteksskole og Ergoterapeutskolerne i Danmark, hvorefter jeg viser et eksempel på den semiotiske vidensorganisering.

\section{Epistemologiske overvejelser}

Følgende Peirce citater danner baggrunden for udviklingen af SKO:

"Three elements go to make up an idea. The first is its intrinsic quality as a feeling. The second is the energy with which it affects other ideas, an energy which is infinite in the here-and-nowness of immediate sensation, finite and relative in the recency of the past. The third element is the tendency of an idea to bring along other ideas with it" (CP 1.135)

Og endvidere:

„Symbols grow. They come into being by development out of other signs, particularly from icons, or from mixed signs partaking of the nature of icons and symbols. We think only in signs. These mental signs are of mixed nature; the symbol-parts of them are called concepts. If a man makes a new symbol, it is by thoughts involving concepts. So it is only out of symbols that a new symbol can grow. Omne symbolum de symbolo. A symbol, once in being, spreads among the peoples. In use and in experience, its meaning grows." (CP 2.302)

Ser vi på det første citat, så består en idé i følge Peirce af tre elementer: en indre følelse, en energi hvormed den kan påvirke andre ideer, og en tendens til at bringe andre idéer med sig. Ud fra idéens anatomi som beskrevet får vi mange informationer. Den indre følelse kan forstås som et potentiale, som ikke er aktualiseret, dette potentiale eksisterer latent og uafhængigt af noget andet. I forhold til Peirces fænomenologiske ståsted er potentialet identisk med idéens førstehed. For at potentialet kan aktualiseres skal det bæres af noget andet - dets objekt eller andethed. Potentialet aktualiseres gennem den energi, hvormed den kan påvirke andre ideer. Det tredje element er idéens tendens til at bringe andre idéer med sig. Dette er elementet, som medierer mellem potentialet og aktualiseringen, og fastholder aspekter af potentialet i aktualiseringen gennem en vanedannelse eller generalitet, som bringer andre idéer med sig. Sagt på en anden måde, det ergoterapeutiske begreb aktivitet konstituerer et tegn - et symbol. Dette begreb indeholder et betydningspotentiale (tænk på alt det begrebet kan tænkes at betyde også udenfor den ergoterapeutiske kontekst) Idet man fortolker begrebet oversætter man det til et 
andet tegn fx aktivitetsfunktion. Dvs. det er aldrig muligt at tolke tegnet i sig selv, man vil altid tolke det som noget andet og altid ud fra en kontekstuel forankring. Dette andet indeholder aspekter af det første og fastholdes i forhold til det første gennem en fortolkningsvane, som modsvarer det tredje. En ergoterapeut vil tolke aktivitet i forhold til vidensdomænet ergoterapi. Hvorimod en person udenfor dette vidensdomæne i sin fortolkning vil aktualisere andre aspekter af begrebets videnspotentiale i overensstemmelse med dennes brug af og erfaring med begrebet. Dette betyder desuden, at begrebers betydningspotentiale er afhængig af det vidensdomæne de indgår i, og deres videnskommunikation er afhængig af det vidensniveau fortolkeren har. Dvs. man spejler sit vidensniveau i tegnet, som kommunikerer betydning relativt til dette vidensniveau - derfor kan man kun tolke tegn, man har kendskab til på forhånd. Indenfor vidensdomæner er der en forventning om, at man tolker fagbegreber hidrørende vidensdomænet nogenlunde ens, og at denne fortolkning er suveræn for vidensdomænet, derfor modtager en ergoterapeut mere viden fra aktivitet i en ergoterapeutisk kontekst end en organist, som omvendt modtager mere viden fra begrebet kontrapunkt i en musisk kontekst end en bibliotekar osv. Samler vi op på Peirces citat får vi antydningen af at viden er:

Evolutivt (tidsligt og skabt gennem fortolkningsvaner)

Pragmatisk (fortolkningsvaner skabt gennem brug og erfaring)

Lokalt forekommende (dvs. ikke-universalistisk men lokaliserbart i forhold til vidensdomæner ${ }^{2}$ )

Forholder vi dette til det andet citat om symbolernes vækst, så får vi en forståelse af det epistemologiske grundlag for SKO. Symboler vokser gennem brug og erfaring, dvs. dets betydning vokser og forankres. En idé, som i øvrigt er identisk med et tegn og i tilfælde af at der er tale om et menneskeskabt tegn er tegnet konventionelt og et symbol, har en tendens til at bringe andre tegn med sig, dvs. symbolet vokser gennem brug og erfaring. Viden består på denne måde af et tætmasket tegn-net med mange relationer.
Så vidt epistemologien for det semiotiske vidensbegreb. Dvs. et fagbegrebs betydning er defineret gennem dets relationer, og det er disse relationer SKO er interesseret $\mathrm{i}$ at kortlægge.

\section{Det hyperbolske udviklingsprincip}

$\mathrm{Nu}$ har vi en epistemologisk tilgang til viden, som siger at viden oppebæres af tegn, som vokser gennem brug og erfaring i lokale sammenhænge. Vi har en idé om, at brugen og erfaringen bringer andre tegn med sig, som forankrer og forstærker den idé, vi startede med. Med denne teori er det oplagt at antage, at vi kan se nærmere på et vidensdomæne og finde dets fundamentale idé, den idé som skabte og skaber grundlaget for vidensdomænet videre udvikling. Denne fundamentale idé benævner jeg et fundamentaltegn (Thellefsen 2002). Omkring fundamentaltegnet vokser betydningen gennem potentialets fastholdelse af utallige begrebsrelationer. Symbolet vokser. I det følgende skal vi se nærmere på, hvordan et tegn bliver til et symbol. Processen er vigtigt, fordi det giver os en grundlæggende forståelse for hvorfor og hvordan fagsprog kan oppebære stabil viden. Det er Peirces teori om det hyperbolske udviklingsprincip, der kan give os denne indsigt. Peirce skriver:

"This theory is that the evolution of the world is hyperbolic, that is, proceeds from one state of things in the infinite past, to a different state of things in the infinite future. The state of things in the infinite past is chaos, tohu bohu, the nothingness of which consists in the total absence of regularity. The state of things in the infinite future is death, the nothingness of which consists in the complete triumph of law and absence of all spontaneity. Between these, we have on our side a state of things in which there is some absolute spontaneity counter to all law, and some degree of conformity to law, which is constantly on the increase owing to the growth of habit. The tendency to form habits or tendency to generalize is something which grows by its own action, by the habit of taking habits itself growing. 
Its first germs arose from pure chance. There were slight tendencies to obey rules that had been followed, and these tendencies were rules which were more and more obeyed by their own action. There were also slight tendencies to do otherwise than previously, and these destroyed themselves. To be sure, they would sometimes be strengthened by the opposite tendency, but the stronger they became the more they would tend to destroy themselves. As to the part of time on the further side of eternity which leads back from the infinite future to the infinite past, it evidently proceeds by contraries." (CP $8.318 \mathrm{~min}$ kursivering)

Det ene vigtige element i citatet er beskrivelse af evolutionen, som har en ideel slutning forskellig fra begyndelsen. Nu skal man ikke lade sig forvirre af, at Peirce diskuterer det hyperbolske udviklingsprincip på en kosmologisk baggrund. Udviklingsprincippet $b ø r$ forstås universelt, og derfor kan vi bruge det til at beskrive et vidensdomænes udvikling fra undfangelsen af idéen (ikonet) til symbolet er skabt og begynder at vokse og bringe andre idéer med sig. Det andet vigtige element i citatet er, at evolutionen baserer sig på to grundlæggende fænomener: 1. tilfceldighed og 2. tendens til vanedannel$s e$. Det er forholdet mellem disse elementer, der skaber fremdriften i evolution. Bevægelsen går fra tilfældighed imod vanedannelse - fra ikon til symbol. Symbolet betegner den vanedannelse, der fastholder betydningen $i$ tegnet og hvis vigtigste opgave er at fjerne det spontane element, der eksisterer i et tegn. Man kan sige, at jo mere indgroet en fortolkningsvane er, des mindre rum for spontanitet eller udviklingspotentiale eksisterer der i tegnet. Forestiller man sig en hat, da tvinger tegnet mig til at tolke det som en hat gennem den brug og erfaring, jeg har med hatten, og som har givet hatten dets betydningspotentiale. Jeg kan ikke umiddelbart ændre tegnets fortolkningsmæssige stabilitet. Jeg kan naturligvis vælge at kalde hatten en sodavand, men går jeg ind $i$ en tøjforretning, og beder om en sodavand vil ekspedienten ikke forstå hvad jeg mener, i hvert fald ikke når jeg forklarer ham, hvad jeg mener en soda- vand er. Tegn i form af symboler levner på grund af deres konventionalitet og fortolkningsmæssige stabilitet begrundet i sociale vanedannelser ikke megen plads til fortolkningsfrihed. Pointen er naturligvis, at fagbegreber som symboler også er konventionaliserede, og deres betydning er skabt gennem vidensdomænets fortolkningsmæssige vanedannelser - gennem aktørernes brug og erfaringer. Fagbegreber er stabile. Og på grund af denne stabilitet er det muligt at organisere vidensdomænets viden i overensstemmelse med dets fagbegreber. Men som allerede antydet i epistemologien, så er vidensdomænets viden ikke organiseret i pæne alfabetiske rækker som uden problemer kan overføres til andre vidensdomæner. Vidensdomænernes vidensstrukturer er ikke-universelle, men lokale. Hvad skal vi så stille op? Hypotesen er følgende: Et vidensdomænes viden er primært organiseret omkring dets fundamentaltegn. Fundamentaltegnet er et betydningspotentiale, der aktualiseres gennem dets relaterede begreber, som indeholder aspekter af dette betydningspotentiale, men forskudt derfra. Det betyder, at man i et vidensdomæne gennem fortolkninger og fortolkningers fortolkninger osv., konstruerer et vidensunivers bestående af begrebsrelationer med udgangspunkt i fundamentaltegnet. Jeg vil underbygge denne hypotese gennem resten af artiklen. I det følgende skal vi se nærmere på vidensdomænet ergoterapi for dels at identificere dets fundamentaltegn og dels at give eksempler på hvordan man kan organisere dets viden i overensstemmelse med den semiotiske vidensorganiseringsmetode. (se nedenfor)

\section{Ergoterapi}

Lad os med ovenstående i baghovedet se nærmere på vidensdomænet ergoterapi. Ergoterapi er som fagområde opstået omkring idéen om, at daglige aktiviteter af enhver art kan rehabilitere en patient. Lad os som et eksempel forestille os at en person får en hjerneblødning. Vi må forestille os, at hjerneblødningen har ødelagt en hel del synapser i hjernen, hvorved der er opstået lammelser i dele af patientens krop. Patienten kan nu ikke udføre de mest basale dagligdagsaktiviteter såsom at føre en gaffel op til 
munden, drikke af et glas, lave kaffe, etc. Her kommer ergoterapeuten ind i billedet. Som tankeballast medbringer ergoterapeuten en idé om, at de synapser hjerneblødningen ødelagde som følge af hjerneblødningen kan erstattes (kompenseres for) af andre synapser, ved at træne patienten til igen at kunne drikke af et glas og føre en gaffel op til munden skabes andre synapser. Patienten vil formodentlig aldrig blive lige så god til disse daglige aktiviteter, som hun var før, men vil alligevel være i stand til at kunne eksistere i en opøvet tilstræbt normal hverdag og derigennem få livskvalitet ind i sit liv igen. Når man over en længere tidsperiode har observeret at disse daglige aktiviteter har gavnlig ind ydelse på patienterne, så bliver idéen om daglige aktiviteter fikseret (aha, det kan være det virker! (abduktiv slutning)). Kimen til det ergoterapeutiske vidensdomæne er lagt. Efterfølgende vil denne fælles idé bringe andre idéer med sig og vokse sig stærk og blive til det ergoterapeutiske vidensdomæne. Dette er naturligvis en idealiseret beskrivelse, der skal naturligvis mange mellemregninger til for den fikserede idé bliver et vidensdomæne. Her skal vi bl.a. medregne det omkringliggende samfund, herunder det politiske klima m.m. Men ideen er blevet fasthold og symboliseret, og for så vidt idéen er levedygtigt vil vidensdomænet udvikle sig. Ergoterapien i Danmark ser ud til at have udviklet sig omkring begrebet aktivitet og derfor har dette begreb tiltrukket sig andre ideer simpelthen fordi: The tendency to form habits or tendency to generalize is something which grows by its own action, by the habit of taking habits itself (Collected Papers 8.318). Dette er en selvforstærkende kraft som fastholder betydningen i symbolet, og som gør at vi har en nogenlunde ens forståelse af symboler, og at symbolernes betydning i vidensdomæner bliver fastholdt i overensstemmelse med vidensdomænets målsætninger og politikker. Dette betyder ikke, at symboler ikke kan ændre betydning, men symbolernes træghed (fordi de er konventionaliseret) sikrer en vis fortolkningsstabilitet $\mathrm{i}$ vidensdomænet og denne fortolkningsstabilitet er nødvendig for at et vidensdomæne kan have og udvikle en terminologi. Fagsproget er vidensdomænets rygrad, og det er i fagsproget og dets relationer vi kan identificere vidensdomænets selvforståelse og særegenhed.

\section{Fagsprog}

Indenfor et vidensdomæne er viden struktureret og organiseret omkring en fælles forståelse af et bestemt genstandsområde. Det bør være en konsekvens af ovenstående analyse og gennemgang. Med udgangspunkt i fagbegrebernes kognitive funktioner behøver et vidensdomænes fagbegreber ikke at eksistere som et nedskrevet fagsprog, begreberne er i stand til at eksisterer som tavs viden, hvilket i фvrigt ofte er tilfældet i vidensdomæner, som er under etablering eller primært retter sig imod praksis fx ergoterapi og fysioterapi. Den tavse viden bliver aktualiseret når man på baggrund af en fortolkningsvane udfører en handling. Husk på, at interpretanten i den peirceanske semiotik ikke er identisk med den der fortolker, men er selve fortolkningen. Derfor kan interpretanten godt udtrykke ubevidste handlinger og dermed tavs viden. Konklusionen må være, at fagbegreber er tegn og at de repræsenterer et videnspotentiale, som bliver aktualiseret hver gang, et fagbegreb bliver fortolket. Dermed ser det ud til at en fælles og generel idé (fundamentaltegnet) skaber udviklingen af vidensdomænet og at størstedelen af vidensdomænets viden er centreret og organiseret omkring fundamentaltegnet. Det er vigtigt at forstå, at fundamentaltegnet er et potentiale. Det har en potentiel eksistens, og det manifesterer sig kun igennem fortolkninger. Alligevel fastholder og afgrænser fundamentaltegnet vidensdomænet i forhold til andre vidensdomæner. Og det er indenfor denne afgrænsning at vidensdomænets fagsprog udvikler sig. Dermed er fundamentaltegnet og alle dets relaterede begreber at forstå som et semiotisk skelet. Dette skelet har jeg andetsteds betegnet fundamentaltegnets radialstruktur (Thellefsen 2002). Dermed danner fundamentaltegnet med dets tegn struktur vidensdomænets vidensstruktur, og det er vel og mærket en struktur, der eksisterer uafhængig af den enkelte fortolker. Vidensstrukturen har reel eksistens. 


\section{Semiotiske vidensorganisering i praksis}

Metoden som danner baggrunden for SKO er en videreudvikling af antropologiens eksplorative metode dvs. en undersøgelsesmetodik, der har sit afsæt i den klassiske antropologiske forskningsmetode (her i sagens natur groft forenklet). Antropologen rejste ud til fremmede folkeslag, satte sig på en træstub, og noterede det han observerede, derefter vendte antropologen tilbage til civilisationen, nedskrev og udgav efterfølgende en monografi over sine oplevelser, det kunne fx være forlovelsesritualer blandt Sumatras oprindelige befolkning. Metoden holdt vand indtil de indfødte selv blev i stand til at læse, hvad antropologerne skrev, de kunne simpelthen ikke genkende antropologernes gengivelser af deres gøren og laden. Derfor er det en vigtig pointe, at det er ergoterapeuterne selv, der skal beskrive deres vidensdomæne, ellers ville det blive den gamle antropologiske metodiske fejltagelse om igen. I stedet er der nedsat en redaktionsgruppe bestående af ergoterapeuter der, som en slags fødselshjælpere, med udgangspunkt i deres ,indfødthed“ i ergoterapien, kan guide projektdeltagerne rundt $i$ det ergoterapeutisk vidensunivers. Men hvor starter den eksplorative metode? I tidsrummet 1999 - 2000 foretog jeg en empirisk undersøgelse, hvor 25 ergoterapilærere blev bedt om at liste 25 centrale ergoterapeutiske begreber. Denne unders $\varnothing$ gelse har jeg efterfølgende anvendt til at undersøge om, der forekommer begreber, som ergoterapeuter finder signifikant mere betydende end andre begreber. Jeg har på baggrund af undersøgelsen konkluderet, at aktivitet er unders $\varnothing$ gelsens mest betydende begreb pga. det store antal gange det bliver nævnt. Efterfølgende har jeg rådført mig med ere ergoterapeuter (Gunner Gamborg ${ }^{3}$, Solveig Togsverd ${ }^{4}$, Bente Hartvig ${ }^{5}$, Kirsten Pedersen ${ }^{6}$ for at finde ud af, hvordan alle de a edte aktivitetsbegreber fx hverdags aktiviteter, daglige aktiviteter relaterer til aktivitet. Deraf har jeg konkluderet, at eftersom fx hverdagsaktiviteter, daglige aktiviteter og hele rækken af aktivitetsrelaterende begreber, alle betyder noget $\mathrm{i}$ forhold til aktivitet $\mathrm{i}$ en mălestok, som ingen andre af de nævnte begreber i det empiriske materiale kan fremvise, formoder jeg, at aktivitet er et fun- damentaltegn for ergoterapien. Hypotesen er blevet forelagt ergoterapeuterne uden at hypotesen er blevet modsagt. Vidensorganiseringen starter således med en beskrivelse af aktivitet. Vender vi tilbage til den eksplorative metode, så fungerer begrebet aktivitet som en mulig indgang til det ergoterapeutiske vidensdomæne. Når denne indgang vælges, så får det naturligvis konsekvenser for, hvordan beskrivelsesprocessen forløber. Projektet starter med en grundig beskrivelse af aktivitet og alle dets relaterede begreber. Disse relaterede begreber er, som udgangspunkt, de begreber der er fremfundet i den empiriske undersøgelse, og som indgår i en semantisk relation til aktivitet (fx aktivitetsanalyse, aktivitetsdysfunktion, aktivitetstab, aktivitetsvidenskab, daglige aktiviteter m.v.) Her er det redaktionsgruppen skal være behjælpelig med dels at validere de fremfundne radialer og eventuelt fremkomme med nye. Når redaktionsgruppen har et overblik over de fremfundne relaterede begreber, vil de blive forholdt andre ergoterapeutiske aktører evt. i form af en fokusgruppe i ergoterapien. Når aktivitet og alle dets relaterede begreber er beskrevet, skal redaktionsgruppen se nærmere på de relaterede begrebers radialstrukturer. Dvs. den radialstruktur der eksisterer til aktivitet, kan lagdeles til yderligere radialstrukturer. Det nærmere antal begreber det drejer sig om her, er umuligt at sige noget om, men hver relateret begreb til aktivitet (ca. 30-50 alt efter unders $\emptyset$ gelsernes resultat) besidder også en radialstruktur, som på lignende måde skal beskrives. Disse relaterede begreber besidder igen radialstrukturer og så fremdeles. Det betyder, at beskrivelsen af ,aktivitet" og dets radialsstruktur og radialernes radialstruktur og så fremdeles, formentlig vil give os en grundig beskrivelse af ergoterapien, set gennem aktivitetsbegrebets fokus. Det er endvidere min hypotese, at vi igennem de mange radialstrukturer, som man kan tænke på som et spindelvæv, vil få beskrevet hele begrebsmassen fra den empiriske unders $\varnothing$ gelse. På den led mener jeg, at begreber som ow, ADL, narrativer, funktion, klinisk ræsonnering etc. vil blive indfanget i dette spindelvæv af radialstrukturer, der opstår omkring aktivitet. 
Det følgende eksempel er konstrueret med udgangspunkt i ovennævnte begrebsliste og gennem et samarbejde med ergoterapeuterne har jeg fors $\emptyset \mathrm{gt}$ at organisere nogle af de ergoterapeutiske begreber i forhold til hinanden. Selvom jeg anvender klassifikationsprincipper fra LIS (bl.a. bevægelse fra generel til specifik), er det interessante at det er umuligt at komme frem til begrebernes indbyrdes placering gennem gængse bibliotekariske værktøjer. Vidensorganiseringen dvs. begrebernes indbyrdes forhold og vidensindhold er suveræn for ergoterapien. Det skal understreges at det er et eksempel. Projektet som er et formaliseret samarbejde mellem Institut for kommunikation, Aalborg universitet, Danmarks Biblioteksskole og Ergoterapiskolerne i Danmark samt ETF (Ergoterapeutforbundet) forløber stadigt og ventes ikke færdigt før tidligst efterår 2003, hvor en færdigudbygget hypertekstbaseret encyklopædi over ergoterapiens viden kan præsenteres. Man skal forestille sig eksemplet som en hypertekstbaseret bevægelse ud i radialstrukturen med aktivitet som fikspunkt i radialstrukturen. Omkring aktivitet kredser aktivitetsvidenskab, aktivitetsteori og forebyggelse. Dette er første række af relaterede begreber. I forhold til aktivitet er disse begreb mindre abstrakte. Vælger vi at se nærmere på aktivitetsvidenskab (første række af relaterede begreber) ved at klikke på det, så toner aktivitetsvidenskab frem som centrum i den første række af relaterede begreber, hvor dette begrebs relaterede begreber er ADL, Aktivitetsanalyse og genoptrcening. Jeg vælger at undersøge aktivitetsanalyse. Aktivitetsanalyse toner frem som centrum i anden rækkes relaterede begreber (alt foregår i forhold til aktivitet som fundamentaltegn). Jeg vælger herefter at se nærmere på aktivitetsform (tredje række af relaterede begreber) osv. Eksemplet stopper ved tredje række. Fundamentaltegnet er fremhævet med orange og de valgte begreber er fremhævet med gul.

\section{Aktivitet (metaniveau)}

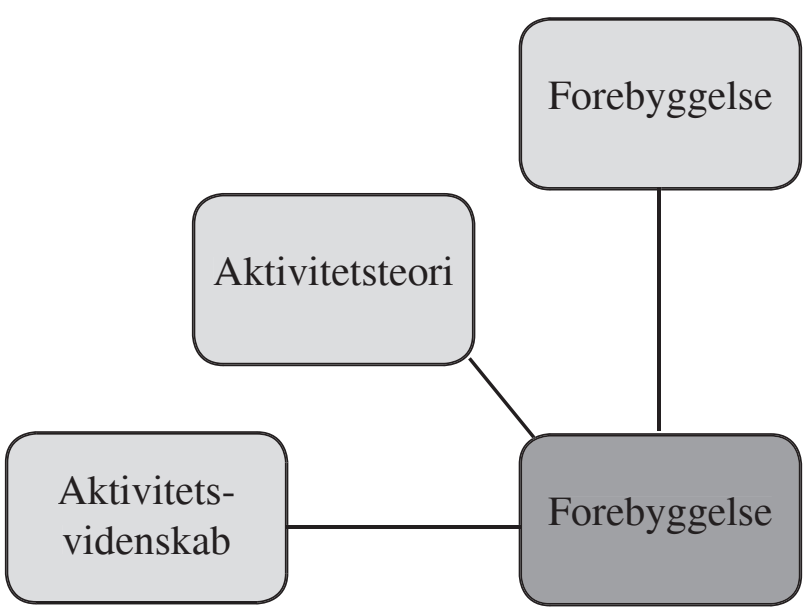

Figur 1. Aktivitet som fundamentaltegn

\section{Første række af relaterede bregreber}

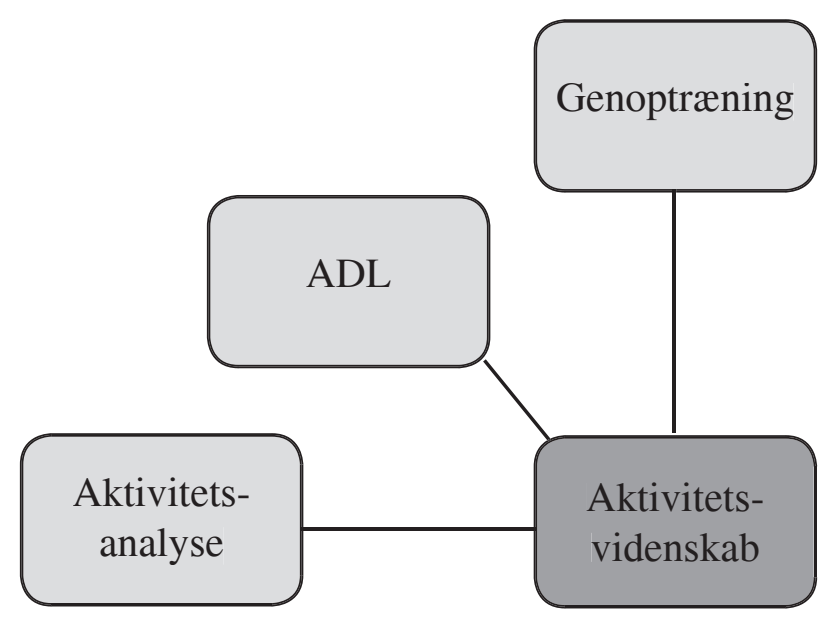

Figur 2. Første rakke af relaterede begreber 
Anden rakke af relaterede begreber

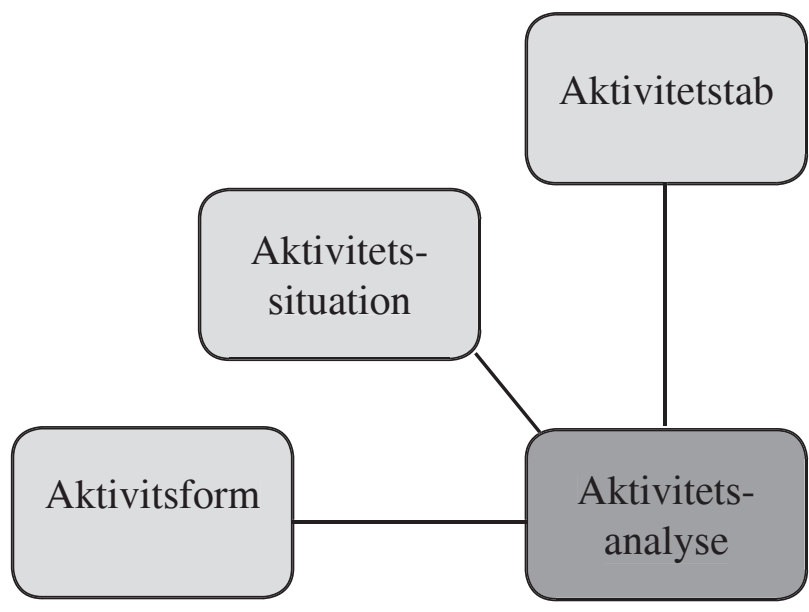

Figur 3. Anden rokke af relaterede begreber

\section{Tredje række af relaterede begreber}

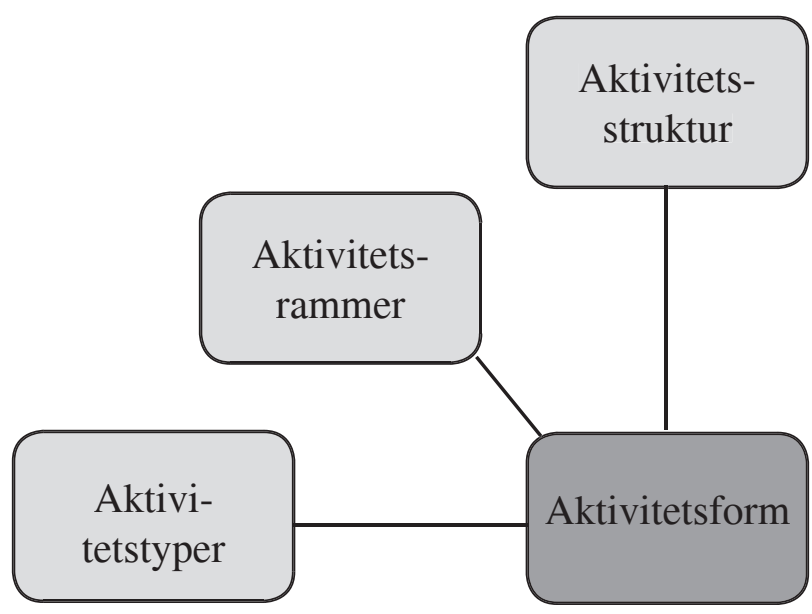

Figur 3. Tredje rokke af relaterede begreber.

Det vigtige ved eksemplet er at få en fornemmelse af, at vi ned igennem strukturen oplever en større grad af specificitet, samtidig med at hvert eneste begreb stadig er fastholdt af fundamentaltegnet. Ingen af ovennævnte begreber kan forstås udenom fundamentaltegnet.
Ud over den grafiske fremstilling som i forhold til det endelige resultat kun er på skitseplanet, så vil encyklopædien også byde på almindelige søgefunktioner, således at man kan søge direkte på et begreb fx aktivitetsform og komme direkte hen til begrebet i strukturen, det vil også være muligt at søge fritekst. Alle begreber vil være beskrevet med abstracts på max. 200 ord primært skrevet af ergoterapeutstuderende på 6. semester. Der vil være henvisninger til primærlitteratur, vigtige forskere såvel indenlands som udenlands. Der vil være henvisninger til beslægtede begreber i begrebsstrukturen, også på tværs af radialerne.

\section{Opsamling}

Den pragmatiske semiotik giver os en god mulighed for at se nærmere på de kognitive strukturer, der aftegner et vidensdomæne. Det synes pt. at være den eneste teori, der er i stand til at afdække de vidensstrukturer, der danner vidensdomænet. Jeg mener at, Peirce med sine teorier omkring idéerne tendens til at bringe andre idéer med sig, symbolernes evne til at vokse gennem brug og erfaring samt det hyperbolske udviklngsprincip har skabt baggrunden for at kunne forstå tegnenes natur. Det er en plausibel antagelse at fagbegreber danner, indeholder og aftegner vidensdomænets vidensindhold. Det virker også plausibelt at antage at vidensdomænets vidensstrukturer udtrykker vanedannelser, fordi vidensdomænets terminologi udtrykker en stabilitet, som gør, at man kan tillægge det enkelte begreb betydning og være sikker på at dette begreb betyder det, der er enighed om at det betyder. At betegne strukturen som en vane er ifølge min overbevisning genial, i vanen ligger der rum for udvikling. Hvilket betyder at man må anerkende at begreberne kan ændre betydning over tid. Det betyder igen, at begreber er dynamiske jf. bevægelsen i det hyperbolske udviklingsprincip, men hastigheden i bevægelsen aftager jo mere indgroet vanen bliver. Konsekvensen af semiotikken er på den led, at vi har et vidensbegreb, der er pragmatisk, evolutivt, og lokalt, men vi har til gengæld en metode som kan håndtere viden som det er fremlagt her. I al beskedenhed mener jeg semio- 
tikken er blevet mulig at implementere i den virkelige verden. Og det er mit håb at det omtalte forskningsprojekt tydeliggøre dette, så har vi endelig sat kursen væk fra den universalistiske vidensforståelse, der i mange år har domineret biblioteksforskningen både nationalt og internationalt.

\section{Noter}

1 Dog deler jeg ikke Søren Briers brug af den kognitive semantik, da denne teori efter min mening ikke er forenelig med Peirces pragmatiske semiotik.

2. Viden er lokaliserbart i forhold til en given kontekst, i denne artikel er det vidensdomænet der er i centrum, men konteksten kunne godt tænkes at være andet end et vidensdomæne. Det ændrer imidlertid ikke ved hvad synes at være et faktum, at viden er ikke-universelt

3. Gunner Gamborg er rektor for Ergoterapeut- og fysioterapeutskolen i Århus.

4. Solveig Togsverd er rektor på ergoterapeutuddannelsen i Aalborg.

5. Bente Hartvig er underviser på ergoterapeutuddannelsen i Aalborg

6. Kirsten Pedersen er underviser på ergoterapeutuddannelsen i Aalborg

\section{Litteratur}

Brier, S. (1994). Information er sølv: om muligheden for en pragmatisk informationsteori baseret på anden ordens kybernetik, semiotik og sprogspilsteori. Danmarks Biblioteksskole, Aalborgafdelingen, Aalborg: Forlaget Biblioteksarbejde.
Brier, S. (1996). Cybersemiotics: A new interdisciplinary development applied to the problems of knowledge organization and document retrieval in information science. Journal of Documentation, 52, (3), 296 - 344.

Brier, S. (2000). Biosemiotics as a possible bridge between embodiment in cognitive semantics and the motivation. Proceedings of Nordic-Baltic Summer Congress of ISI, June 2000, Imatra.

Peirce, C. S. 1931-1966. Collected Papers of Charles Sanders Peirce, 8 vols., ed. by Charles Hartshorne, Paul Weiss, and A. W. Burks. Cambridge, MA: Harvard University Press.

Thellefsen, Torkild \& Thellefsen, Martin (20022003). Pragmatisk semiotik og vidensorganisering. Anvendt semiotic II (arbejdstitel) red. Torkild Thellefsen \& Anne Marie Dinesen. Gyldendal

Thellefsen, Torkild, Brier, Søren, Thellefsen, Martin. 2002-2003 (in press). Problems concerning the process of subject analysis and the practice of Indexing: A semiotic and semantic approach towards user oriented needs in document representation and information searching. Semiotica.

Thellefsen, T. (2000). Firstness and Thirdness displacement : The epistemology within Peirce's three sign trichotomies. C. S. Peirces Digital Encyclopedia. http://www.tr3s.com.br/peirce/home.htm

Thellefsen, Torkild (2002 in press): Semiotic Knowledge Organization : Theory and Method Development. Semiotica. 